\title{
TOXICITY OF EIGHT PESTICIDES TO SPRUCE AND CARAGANA SEED ${ }^{1}$
}

\section{By W. H. CRAM ${ }^{2}$ and O. VAARTAJA ${ }^{3}$}

\author{
W. H. CRAM
}

William Hugh Cram, graduated from the University of Manitoba with B.S.A. (1939) in horticulture, and with M.Sc. (1948) in plant breeding, and from the University of Minnesota with Ph.D. (1951) in plant breeding and genetics. He was Tree Planting Supervisor for the Forest Nursery Station (1941-42) and overseas with the R.C.A.F. (1942-45). Dr. Cram was Horticulturist at the Experimental Farm Indian Head (1945-47) and from 1947 to the present has been Plant Breeder at the Forest Nursery Station, Indian Head.

\section{O. VAARTAJA}

Olli Vaartaja studied at Helsinki University, obtaining his Doctor's Degree in 1951, with silviculture as his major subject. From 1945 to 1951 he conducted silvical, ecological, and forest pathological research for the Finnish Government, mainly at the Institute of Plant Biology and Plant Pathology of Helsinki University. In 1951-1952 he held a post-doctoral fellowship at Yale. Since 1952 he has been employed at the Forest Pathology Laboratory, Saskatoon, where his special field of research is diseases of seedlings.

\section{ABSTRACT}

Pesticides were applied to seeds of Caragana arborescens Lam, and Picea pungens Engelm, at the maximum adhering dosages. The toxicity was evaluated in terms of subsequent germination. Pesticides applied prior to stratification of the seed had little or no influence upon the germination of caragana and spruce seed, with the exception that Ceresan $M$ reduced germination capacity and germination speed of caragana seed and germination speed of spruce seed. Some post-stratification treatments proved detrimental to the germination of seed of both species; Ceresan M, chinosol, and Manzate were essentially lethal; Stauffer N-244, thiram preparates, Spergon SL, and Orthocide 75 proved mildly toxic. Surface sterilization of seed before and after stratification with $a$ $0.5 \%$ solution of mercuric chloride with a water rinse was harmless.

\section{INTRODUCTION}

An approach to controlling damping-off diseases in forest nurseries is through pesticides repeatedly applied on the seedbeds or, in heavy dosages, directly on the seed. Such pesticides must be low in their toxicity to seeds and young seedlings. In this study an attempt was made to select pesticides of low toxicity to seeds of a conifer and of a broad-leaved tree. Eight pesticides representing old and new material of chemically different groups were tested. All are reported as effective fungicides $(2,4,5,6)$ and, in addition, some of them have miticidal and nematocidal properties.

\footnotetext{
${ }^{1}$ Contribution No. 837 from Horticulture Division, Experimental Farms Service, and Contribution No. 189 from Forest Biology Division, Science Service, Department of Agriculture, Ottawa, Canada. Submitted for publication February 14, 1955.

- Plant Breeder, Forest Nursery Station, Indian Head, Saskatchewan.

-Associate Forest Biologist, Forest Pathology Laboratory, Saskatoon, Saskatchewan.
} 


\section{Materials aNd Methods}

Seeds of one seedtree of Siberian pea-tree, Caragana arborescens Lam., and one seedtree of Colorado spruce, Picea pungens Engelm., were utilized for the study. The seeds were stratified by storing in moist sand at $41^{\circ} \mathrm{F}$. for 15 days prior to sowing.

Pesticides, as listed in Table 1, were applied to the seed by agitation, and the excess was screened off. Thus, dosages were dependent upon the adhering capacity of the preparates as well as upon the surface and condition of the

TABLE 1

GERMINATION of SEed of Picea pungens and Caragana arborescens Following Pesticidal Treatments Before and After Sratification (DATA FOR FrRst 15 DAYS)

\begin{tabular}{|c|c|c|c|c|c|}
\hline \multirow{3}{*}{$\begin{array}{c}\text { Tree } \\
\text { species }\end{array}$} & \multirow[b]{3}{*}{ Pesticide } & \multicolumn{4}{|c|}{ Relative germination ${ }^{1}$} \\
\hline & & \multicolumn{2}{|c|}{ Capacity } & \multicolumn{2}{|c|}{ Speed } \\
\hline & & Before & After & Before & After \\
\hline \multirow{8}{*}{$\begin{array}{l}\text { Picea } \\
\text { pungens }\end{array}$} & Mercuric chloride $0.5 \%{ }^{2}$ & 107 & 104 & 94 & 100 \\
\hline & Tersan (thiram $75 \%$ ) & 96 & 96 & 94 & 94 \\
\hline & Arasan (thiram 50\%) & 107 & 110 & 100 & $83^{* *}$ \\
\hline & Stauffer N-244 & 103 & $74 * *$ & 95 & $90^{*}$ \\
\hline & Orthocide (captan $75 \%$ ) & 98 & $63^{* *}$ & 100 & $57^{* *}$ \\
\hline & Manzate (maneb) & 107 & $34 * *$ & 95 & $47 * *$ \\
\hline & Chinosol & 104 & $0 * *$ & 94 & $0 * *$ \\
\hline & Ceresan $M$ (org. mer.) & 87 & $0^{* * *}$ & $76^{*}$ & $0^{* *}$ \\
\hline \multirow{7}{*}{$\begin{array}{l}\text { Caragana } \\
\text { arborescens }\end{array}$} & Orthocide (captan $75 \%$ ) & 98 & 94 & 108 & 99 \\
\hline & Tersan (thiram 75\%) & $75^{*}$ & 99 & 85 & 96 \\
\hline & Mercuric chloride $0.5 \% 2$ & 95 & 100 & 87 & 83 \\
\hline & Arasan (thiram 50\%) & 92 & $81^{*}$ & 112 & $80^{*}$ \\
\hline & Spergon SL (chloranil) & 98 & $62^{*}$ & 103 & $67 *$ \\
\hline & Manzate (maneb) & 99 & $0^{* *}$ & 112 & $0^{* *}$ \\
\hline & Ceresan M (org. mer.) & $57^{*}$ & $0^{* *}$ & $73 *$ & $0^{* *}$ \\
\hline
\end{tabular}

1 in terms of check $=100$, the smaller the value the lower germination capacity and speed.

2 solution followed by water rinse.

3 3-p-chlorophenol-5-methyl rhodanine.

$*$, significantly less than check to $5 \%$ and $1 \%$ level, respectively.

seed. Both pre- and post-stratification applications were tested. In addition to the pesticides in dust form, mercuric chloride was tested by dipping the seed in a $0.5 \%$ solution followed by a rinsing in distilled water.

Phytotoxicity of the pesticides was evaluated in terms of the germination capacity and germination speed of the treated seed in comparison with those of non-treated seed. Flats filled with finely-screened sand were utilized for the germination test in the greenhouse. The sand was sterilized by flushing with hot water. A split plot design was followed with eight main plots of fungicideš, which were divided into three treatment subplots of check, pre-, and poststratification applications. Each subplot consisted of 50 seeds and there were 
three replications. Non-germinated seeds were screened out of the sand at the conclusion of the test and classified as sound or damage, empty (spruce), or hard (caragana). Germination capacity was calculated from the emergence data in terms of the germination percentage for all seed sown, less empty or hard seeds. Germination speed was calculated in terms of the index rate of germination (1). These values were subjected to analyses of variance and the significance of differences determined.

\section{RESULTS}

Table 1 shows the results, in terms of checks $=100$, as recorded 15 daýs after sowing. Toxicity by a fungicide to seeds is suggested by significant differences $*$ and ${ }^{* *}$ in germination between non-treated (check) and treated seed. Similar results were obtained 23 days after sowing. However, some reductions in germination in earlier data were not significant in later data, but the toxicity was still evident in terms of reduced germination speed.

As can be seen in Table 1, all fungicides showed toxicity in some cases, but the degree varied greatly. The toxicity might have been less if lower dosages had been applied. The maximum adhering dosages, as applied, is higher than commonly practiced, for instance, in cereal seed treatments.

The results with mercuric chloride, though reported in Table 1, are not comparable with the other results because the residual effect was avoided by rinsing after the application of the chemical. This was the only treatment showing no significant phytotoxicity.

Although all fungicides were toxic to seed in some cases, the low toxicity or some fungicides in several cases should be noted.

\section{Discussion}

The high toxicity of mercury compounds to spruce and caragana seed, as exhibited by Ceresan $M$ treatments in Table 1, is in agreement with previous reports (3) for pine seed. Dipping seeds in mercuric chloride was harmless in this study while it was toxic to pine seed in another study (3). This is probably due to the fact that in this study a water rinse followed the dipping while in the other study no rinse was made.

Thiram fungicides and Orthocide (captan), although slightly toxic in certain cases, were in general harmless to seeds as shown by Table 1 . These and closely related fungicides have been reported as being non-toxic to seeds of various pines $(2,3,5)$ and Betula verrucosa $(5)$. As a result of this investigation thiram and captan have been selected for further study.

\section{REFERENCES}

1. BARTLETT, N. S., 1937. Some samples of statistical methods of research in agriculture and applied biology. Roy. Stat. Soc. Supp. 4:137-170.

2. BERBEE, J. G., FLORA BERBEE, and W. H. BRENA., 1953. The prevention of dampingoff of coniferous seedlings by pelleting seed. Phytopath. $43: 466$.

3. HAMILTON, T. R. and L. W. R. JACKSON, 1951. Treatment of shortleaf and loblolly pine seed with fungicidal dust. Plant Dis. Rep. 35: 274-276.

4. RICH, SAUL, 1954. Miticidal action of barium and manganese ethylene disdithiocarbamates. Phytopath, 44: 387.

5. VAARTAJA, O., 1954. Screening fungicides non-toxic to germinating tree seed. Phytopath. 44: 509.

6. Experimental fungicide-nematocide compound N-244, 1952. Stauffer Chemical Co., Sept. 10. 